\title{
Evidence for the essential role of prostaglandins for parturition in a marsupial, Macropus eugenii
}

\author{
M. B. Renfree*, G. Shaw ${ }^{*}$ and T. P. Fletcher ${ }^{\dagger}$ \\ Department of Anatomy, Monash University, Clayton, Victoria 3168, Australia
}

\begin{abstract}
Female tammar wallabies were treated prepartum with the prostaglandin synthase inhibitor indomethacin, with or without the dopamine agonist bromocriptine, to suppress the peripartum pulses of plasma prostaglandin and prolactin. The animals were observed continuously to detect birth, and a series of blood samples taken to define the hormonal profiles before and immediately after parturition. Birth was observed in ten of twelve control animals but not in the six animals treated with indomethacin alone or the six animals treated with indomethacin and bromocriptine. Indomethacin disrupted the normal profile of $\mathrm{PGF}_{2 \alpha}$ metabolite 13,14-dihydro-15-keto-prostaglandin $\mathrm{F}_{2 \alpha}$ (PGFM) concentrations, and in the females treated with bromocriptine plus indomethacin the pulse of prolactin normally seen at parturition was completely abolished. Plasma progesterone concentrations fell slowly in treated animals, whereas in control animals they fell steeply immediately after parturition. Postpartum oestrus was delayed or absent in treated and most control animals, suggesting that the frequent blood sampling and disturbances in the peripartum period interfered with these endocrine processes. We conclude that prostaglandin is essential for normal birth. Prolactin, in the apparent absence of a prostaglandin peak, does not induce birth or rapid luteolysis. Prostaglandin release may synchronize the rapid fall in progesterone concentrations associated with birth, but in the absence of this signal, the corpus luteum undergoes a less rapid, autonomous decline.
\end{abstract}

\section{Introduction}

In the tammar Macropus eugenii there is a pulse of prolactin and prostaglandin in the peripheral plasma at the time of birth. The concentration of $\mathrm{PGF}_{2 \alpha}$ metabolite PGFM rises to a peak value of about $1 \mathrm{ng} \mathrm{ml}^{-1}$ within $10 \mathrm{~min}$ of birth (Lewis et al., 1986) and then declines to less than $200 \mathrm{pg} \mathrm{ml}^{-1}$ within $45 \mathrm{~min}$ and is basal by $2 \mathrm{~h}$ post partum. There is also a peak of prolactin at parturition in pregnant female tammars (Tyndale-Biscoe et al., 1983) and Bennett's wallabies (Macropus rufogriseus) (Loudon et al., 1990). In tammars, this pulse of prolactin occurs only in pregnant females and appears to be responsible for inducing rapid luteolysis (indicated by a significant fall of progesterone within $8 \mathrm{~h}$ of birth) earlier than occurs in the non-pregnant cycle (Tyndale-Biscoe et al., 1988). The prolactin peak is apparently triggered by a rise in $\mathrm{PGF}_{2 \alpha}$ (Hinds et al, 1990). Although luteolysis is not essential for parturition (Ward and Renfree, 1984), it is thought that prolactin is necessary for both luteolysis and parturition (Tyndale-Biscoe et al., 1983, 1988). However, when the peripartum prolactin pulse is abolished with bromocriptine, neither parturition nor luteolysis are inhibited, and the peripartum peak in plasma PGFM concen-

Present addresses: *Zoology Department, The University of Melbourne, Parkville, Victoria, Australia 3052 and †Prince Henry's institute of Medical Research, PO Box 152, Clayton, Victoria, Australia 3168.

Received I June 1994. trations is not affected (Fletcher et al., 1990). These experiments give conflicting conclusions, and suggest that both prolactin and prostaglandin can induce luteolysis in wallabies. The normal sequence of events appears to involve a signal of fetal origin (Tyndale-Biscoe and Renfree, 1987; Tyndale-Biscoe et al., 1988) that induces, directly or indirectly, prostaglandin release from the uterus which in turn releases a pulse of prolactin that induces a progesterone decline (Renfree et al., 1989; Hinds et al., 1990; Hinds, 1991; Renfree, 1993). However, while it was clear that tammars can give birth without prolactin if prostaglandin is present (Fletcher et al., 1990), there has been no study of parturition after administration of a prostaglandin inhibitor. Thus, the relative roles of these two hormones in the birth process remain unclear.

This study was designed to test the role of prostaglandin in parturition and luteolysis in the presence or absence of prolactin, using the prostaglandin synthase inhibitor indomethacin and the dopamine agonist bromocriptine.

\section{Materials and Methods}

\section{Animals}

The tammars used in this study were from a breeding colony established at Monash University with animals originally from Kangaroo Island, South Australia. Husbandry and handling 
were as described by Renfree and Tyndale-Biscoe (1978) and Fletcher and Renfree (1988). The females were housed with males until placed in the observation pens.

Pouch young were removed (day 0 ) during the breeding season from 15 females in February (group 1) and from another 15 females in March 1990 (group 2). All females were adults (4.2-5.8 kg body mass) in lactational quiescence and presumed to be carrying blastocysts in lactational diapause, so that removal of pouch young (RPY) would result in reactivation and births 26-27 days later (Tyndale-Biscoe and Renfree, 1987). Females were placed in two specially constructed 'pens' with Perspex sides and front, elevated to eye level to facilitate observations. Starting at midnight on day 24 after RPY, the animals were watched continuously for signs of birth. Birth could be anticipated, as immediately before birth females begin their characteristic birth behaviour (Renfree et al., 1989). Continuous observations ceased at midnight on day 27 , when 5 controls had given birth. Females were placed with males $1 \mathrm{~h}$ post partum in a small outdoor pen. Immediately after birth, but before attachment to the teat, the neonatal young were removed and weighed and their head lengths measured with a vernier calliper, then replaced close to the teats where they attached themselves within $2 \mathrm{~min}$. They were removed again $12 \mathrm{~h}$ after birth, weighed, and replaced in the pouch or directly on the teat. Pouch young were checked for reattachment at each blood sampling period, and mothers were checked for the presence of a copulatory plug.

Non-parturient animals were examined by laparotomy on day 30 to assess their reproductive status. The diagnosis of pregnant (postpartum) or not pregnant was based upon the appearance of the uterus (Ward and Renfree, 1984). The entire operation took less than $10 \mathrm{~min}$ and animals had recovered from anaesthesia by $15 \mathrm{~min}$. Anaesthesia was induced by injection of $60 \mathrm{mg}$ pentobarbitone sodium $\mathrm{ml}^{-1}$ (Abbott Laboratories, Kurnell, NSW), via the lateral tail vein. Animals that had retained a fetus were killed by an anaesthetic overdose and the entire reproductive tract was removed. The fetus was dissected free of the uterus and embryonic membranes, weighed and the crown-rump length and head length measured.

Care and treatment of the animals conformed to the National Health and Medical Research Council of Australia 1990 guidelines 'Australian Code of Practice for the Care and Use of Animals for Scientific Purposes' and all experiments were approved by Institutional Animal Experimentation Ethics Committees.

\section{Solutions for injection}

Bromocriptine (CBI54: Sandoz Pharmaceuticals, Sydney) was prepared by dissolving $250 \mathrm{mg}$ of the dry powder and $250 \mathrm{mg}$ of DL-tartaric acid in $5 \mathrm{ml}$ warm saline plus $5 \mathrm{ml} 70 \%$ $(\mathrm{v} / \mathrm{v})$ alcohol, giving a final solution containing $25 \mathrm{mg}$ bromocriptine $\mathrm{ml}^{-1}$. Animals were injected i.m. with $0.2 \mathrm{ml} \mathrm{kg}^{-1}$ tartaric acid in saline/ethanol (controls) or $0.2 \mathrm{ml} \mathrm{kg} \mathrm{kg}^{-1}$ $\left(5 \mathrm{mg} \mathrm{kg}^{-1}\right)$ bromocriptine and tartaric acid in salinelethanol (bromocriptine group). Indomethacin $(50 \mathrm{mg}$ ) was administered orally (Indocid: $25 \mathrm{mg}$ capsules, Merck, Sharp and Dohme, Granville, NSW), or as the powder (Sigma Chemical Co.,
St Louis, MO) which was dissolved in $2 \mathrm{ml}$ ethanol plus $17 \mathrm{ml}$ peanut oil to give a solution of $60 \mathrm{mg} \mathrm{ml}^{-1}$ for i.m. injections.

\section{Injection regimen}

In trial 1 a single injection of bromocriptine was given at $16: 00 \mathrm{~h}$ on day $24 \mathrm{RPY}$ and, from midnight of day 24 , indomethacin capsules were given orally to the experimental animals each $8 \mathrm{~h}$ until 4 of 6 controls had delivered their young. In trial 2 indomethacin solution was given by i.m. injection from midnight on day 24 each $8 \mathrm{~h}$ until 4 of 6 controls had delivered their young. Control animals in both trials received vehicle injections or an oral placebo (empty gelatine capsule). Indomethacin was given by injection in the second trial as this was an easier means of delivery.

\section{Collection of blood samples}

Blood samples $(2.5 \mathrm{ml})$ were taken from the lateral tail vein on days 3-10 after RPY and the plasma assayed for progesterone. Only those animals in which the early progesterone pulse, indicative of a reactivated corpus luteum (Hinds and Tyndale-Biscoe, 1982), was detected were used in this experiment. Blood samples were then taken each morning at 09:00 $\mathrm{h}$ from the day of injection (day 24 RPY) until parturition was observed. Samples were also taken as close to birth as possible (i.e., when birth behaviour began) whilst minimizing any disturbance to the animal. Since birth could not be predicted before the onset of parturient behaviour, prebirth sampling times were not closely grouped. A sample was taken as soon as the young entered the pouch (mean time of sample $10 \mathrm{~min}$ after birth), and further samples were taken at 0.5, 1, 1.5, 2, 3, $4,6,8,16,24,32,40$ and $48 \mathrm{~h}$ after birth for assays of PGFM, prolactin, oestradiol, progesterone and LH. Sample volume varied between 1.5 and $5 \mathrm{ml}$ depending on which hormones were to be assayed at each point. This minimized the total volume of blood taken through the experiment and prevented significant changes in haematocrit values. Samples at some of these time points were missed because simultaneous attention was demanded by other wallabies. All blood was withdrawn into heparinized syringes, centrifuged at $4^{\circ} \mathrm{C}$ for $10 \mathrm{~min}$ at $1700 \mathrm{~g}$, and plasma stored at $-20^{\circ} \mathrm{C}$ until assayed.

\section{Radioimmunoassays}

All samples from each animal were analysed for each hormone in a single assay run to eliminate interassay variation as a source of error. Hormone concentrations were calculated by the method of Burger et al. (1972). Two new assays for progesterone and $\mathrm{LH}$ developed in our laboratory are described below.

Reagents. Buffer chemicals and organic solvents were Analar Grade from Ajax Chemicals (Auburn, NSW) or BDH (Port Fairy, Victoria). Anhydrous ethyl ether was A.R. Grade from Mallinkrodt (Clayton, Victoria) and $n$-hexane was HPLC Grade from Ajax Chemicals. Sulphur-free toluene was from May and Baker (West Footscray, Victoria) and Teric X10 was 
from ICI (Melbourne, Victoria). Unlabelled steroids were purchased from Steraloids Inc. (Wilton, NH).

Progesterone assay. Progesterone was measured by radioimmunoassay using antiserum no. 9817 kindly provided by R. I. Cox, CSIRO Division of Animal Production, Prospect, NSW. This antiserum was raised in sheep against progesterone-11a-hemisuccinate conjugated to human serum albumin. Specificity of the antiserum had been tested by the method of Abraham (1969). The crossreactions of the antiserum with steroids structurally related to progesterone were as follows: progesterone $100 \%$, 11ß-hydroxyprogesterone $6.0 \%, \quad 17 \alpha$-hydroxyprogesterone $<1 \%, \quad 20 \alpha$-hydroxyprogesterone $<1 \%$, 20 $\beta$-hydroxyprogesterone $<1 \%$, $5 \beta$ pregnane-3 $\alpha$-20 $\alpha$-diol $<1 \%$, pregnenolone $<1 \%, \quad 17 \alpha$ hydroxypregnenolone $<1 \%$, oestradiol $<1 \%$, androstenedione $<1 \%$, corticosterone $<1 \%$, 11-deoxycorticosterone $1.5 \%$, cortisol $<1 \%$ and 11-deoxycortisol $<1 \%$.

Assay procedure. Progesterone was extracted by transferring $1 \mathrm{ml}$ plasma to $20 \mathrm{ml}$ screw capped glass tubes (Crown Corning, Sydney) with $8 \mathrm{ml}$ hexane:ethyl acetate (95:5, v:v) and shaking for $10 \mathrm{~min}$ on a horizontal tube shaker at about $1 \times 10 \mathrm{~cm}$ excursion $\mathrm{s}^{-1}$. The aqueous and organic phases were allowed to separate and the aqueous phase was frozen in a bath of solid $\mathrm{CO}_{2}$-ethanol. The organic phase was decanted to $13 \mathrm{~mm} \times 100 \mathrm{~mm}$ test tubes and dried under a stream of dry, filtered air. The extracts were dissolved in $250 \mu \mathrm{l}$ assay buffer (0.01 mol sodium phosphate $\mathrm{I}^{-1}$, $\mathrm{pH} 7.0$; with $9.0 \mathrm{~g} \mathrm{NaCl} \mathrm{I}^{-1}$, $1 \mathrm{~g}$ gelatine $\mathrm{I}^{-1}, 1 \mathrm{~g} \mathrm{NaN}_{3} \mathrm{I}^{-1}$ ) and allowed to equilibrate for at least $4 \mathrm{~h}$. After equilibration, duplicate $100 \mu \mathrm{l}$ aliquots of the redissolved extract, or standards $(0$, and $2-800 \mathrm{pg}$ in $100 \mu \mathrm{l})$, were mixed with $100 \mu \mathrm{l}$ antiserum no. 9817 (diluted 1:40 000 with assay buffer) and $100 \mu] \quad\left[1,2,6,7^{3} \mathrm{H}\right]$ progesterone (Amersham, North Ryde, NSW), diluted with assay buffer to give approximately 5000 c.p.m. in $100 \mu \mathrm{l}$ ), mixed on a SMI Multitube vortexer (American Dade, Miami, FL) and incubated overnight at $4^{\circ} \mathrm{C}$. Free and antibody-bound radioactive progesterone were separated by mixing with $400 \mu \mathrm{l}$ dextran coated charcoal (Dextran T-70, Pharmacia, West Melbourne, Victoria) and activated charcoal (Merck, Darmstadt) diluted to $0.025 \%$ and $0.25 \%$, respectively, and incubating at $4{ }^{\circ} \mathrm{C}$ for $10 \mathrm{~min}$. The mixture was centrifuged at $1700 \mathrm{~g}$ for $15 \mathrm{~min}$ in a refrigerated centrifuge and the supernatant containing the antibody-bound hormone was decanted to pico-vials (Canberra Packard, Mt Waverley, Victoria) and mixed with $4 \mathrm{ml}$ scintillation fluid (5.5 g 2,5-diphenyloxazole $1^{-1}$ of toluene: Teric X10 mixed in the proportion of $2: 1 \mathrm{v}: \mathrm{v})$. Radioactivity was measured in a Packard liquid scintillation counter model $300 \mathrm{C}$.

Assay validation. The efficiency of the extraction procedure was $88 \%$, as determined by the recovery of radioactive progesterone equilibrated with tammar plasma. The sensitivity of the assay, calculated as the lowest standard which differed from the zero standard by more than twice the standard deviation of the zero standard multiplied by the correction factor derived from procedural losses, was $28 \mathrm{pg}$ progesterone $\mathrm{ml}^{-1}$ ( $n=6$ assays). Accuracy was determined by addition of $200,400,500$ and $800 \mathrm{pg}$ of progesterone to aliquots from a tammar plasma pool which were extracted and assayed as described above. The average measured concentrations were within $\pm 8.0 \%$ of the values expected. The regression equation for progesterone recovered from plasma was $y=1.03 x$ +241.63 and $r=0.99$. The precision of the assay was evaluated by multiple determination of aliquots from the plasma pools included in every assay. The interassay coefficient of variation (CV) for two quality control pools containing $482.2 \pm 72.1$ (mean $\pm \mathrm{SD}$ ) and $389.5 \pm 64.2 \mathrm{pg}$ progesterone $\mathrm{ml}^{-1}$ were $14.9 \%$ and $16.8 \%$, respectively ( $n=6$ assays). The intra-assay CV for two different quality control pools containing $522.5 \pm 35.9$ (mean $\pm S D, n=6)$ and $742.7 \pm 73.9(n=8) \mathrm{pg}$ progesterone $\mathrm{ml}^{-1}$ were $6.9 \%$ and $9.9 \%$, respectively. Solvent and buffer blanks were consistently below the sensitivity of the assay.

Oestradiol assay. Oestradiol was measured by the method of Shaw and Renfree (1984) validated for tammar plasma, using antiserum S6181 kindly provided by R. I. Cox, CSIRO Division of Animal Production, Prospect, NSW. The sensitivity was $4 \mathrm{pg} \mathrm{ml}^{-1}$. The interassay CV for two plasma pools containing $10.3 \pm 1.3$ and $23.4 \pm 4.3 \mathrm{pg}$ oestradiol $\mathrm{ml}^{-1}$ were $12.3 \%$ and $18.3 \%$, respectively ( $n=3$ assays). The intra-assay $C V$ was $5.33 \%$. Solvent and buffer blanks were consistently below the sensitivity of the assay.

Prolactin assay. Prolactin was measured by the doubleantibody heterologous radioimmunoassay described by Gordon et al. (1988), using antibody 33/1-8 kindly provided by A. S. McNeilly, MRC Reproductive Biology Unit (Edinburgh). The prolactin standard was ovine $\mathrm{NIH}-\mathrm{oPrl}-\mathrm{SI} 2$ and the radioactive labelled hormone was NIADDK-oPrl-12. The assay sensitivity was $2 \mathrm{ng} \mathrm{ml}^{-1}$. The intra-assay $\mathrm{CV}$ for a plasma pool containing $15 \mathrm{ng} \mathrm{ml}^{-1}$ was $8 \%$ and the interassay $\mathrm{CV}$ for three plasma pools containing $9.2 \pm 1.7,53.2 \pm 2.3$ and $267.7 \pm 18.2 \mathrm{ng} \mathrm{ml}^{-1}$ (two sets of duplicate samples in two assays) were 18.24 .4 and $6.8 \%$, respectively.

LH assay. LH was measured by a double-antibody heterologous radioimmunoassay validated for tammar plasma using rabbit anti-rat antiserum NIDDK-anti-rLH-S-10 with NIH-oLHS23 as standard. The radioactive labelled hormone was NIDDK-rLH-I6 iodinated by the lactoperoxidase method of Thorell and Johannson (1971). Unreacted ${ }^{125} \mathrm{I}$ and ${ }^{125} \mathrm{I}$-labelled LH-I6 were separated on a Sephadex G-25 M mini-column (PD-10, Pharmacia) and the ${ }^{125}$ I-labelled LH fraction further purified on a Sephadex G-100 column $(80 \mathrm{~cm} \times 1.8 \mathrm{~cm})$. The labelled hormone had specific activity in the range from 80 to $100 \mu \mathrm{Ci} \mu^{-1}\left(3.0-3.7 \mathrm{MBq} \mathrm{g}^{-1}\right)$ and was used as soon as possible after iodination. The second antibody was goat anti-rabbit gamma globulin (GAR no. 10) prepared at the Anatomy Dept, Monash University. Precipitation of the second antibody-first antibody bound hormone complex was aided by addition of $6 \%(\mathrm{w} / \mathrm{v})$ polyethylene glycol (PEG, BDH Australia). Dilutions were made in $0.05 \mathrm{~mol} \mathrm{PBS} 1^{-1} \mathrm{pH} 7.4$ (5.68 $\mathrm{g} \mathrm{Na}_{2} \mathrm{HPO}_{4}, 1.56 \mathrm{~g} \mathrm{NaH}_{2} \mathrm{PO}_{4} \cdot 2 \mathrm{H}_{2} \mathrm{O}, 8.18 \mathrm{~g} \mathrm{NaCl}$ made up to $1 \mathrm{l}$ with glass distilled water) and PBS-BSA (PBS $+0.2 \%$ BSA fraction V: Commonwealth Serum Laboratories, Parkville, Victoria) with $0.01 \% \mathrm{NaN}_{3}$. 
Assay procedure. Frozen antiserum (LH-S-10, diluted 1:450 with distilled water) was thawed and further diluted 1:10 with PBS-BSA containing normal rabbit serum (NRS, 1:1000 dilution). Frozen NIH-oLH-S23 was thawed and a standard curve $(0.0195-10.0 \mathrm{ng}$ in $500 \mu \mathrm{l})$ constructed by double dilution with PBS-BSA.

Plasma samples (50 or $100 \mu \mathrm{l}$ ), pituitary homogenates $(100 \mu \mathrm{l})$ and standards $(500 \mu \mathrm{l})$ were transferred to $12 \mathrm{~mm} \times 75 \mathrm{~mm}$ plastic disposable test tubes (Johns Disposable Products, Springvale, Victoria) and brought to $500 \mu \mathrm{l}$ with PBS-BSA. Two-hundred microlitres of diluted LH-S-10 was added to each tube except the nonspecific binding and total radioactivity tubes. The tubes were mixed on a multi-tube vortexer and incubated overnight at $4^{\circ} \mathrm{C}$. One-hundred microlitres of ${ }^{125} \mathrm{I}$-labelled rLH- 16 was then added to all tubes, which were mixed and incubated overnight at $4^{\circ} \mathrm{C}$. Frozen second antibody (GAR no. 10) was thawed and diluted 1:100 with PBS-BSA and $200 \mu \mathrm{l}$ were added to each tube, which were mixed and incubated for $4 \mathrm{~h}$ at $4^{\circ} \mathrm{C}$. Plasma $(200 \mu \mathrm{l})$ from a low LH plasma pool was added to the standards and PBS-BSA

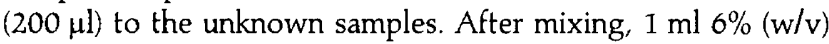
PEG was added to all tubes except the total radioactivity tubes. The tubes were again mixed and allowed to stand for about $30 \mathrm{~min}$. Free and antibody-bound hormone were separated by centrifugation at $1700 \mathrm{~g}$ for $45 \mathrm{~min}$ in a Beckman J6-B refrigerated centrifuge (Beckman Instruments, Mt Waverley, Victoria). The supernatant containing the free hormone was aspirated and the radioactivity in the antibody-bound fraction was counted in a LKB-Wallac 1261 Multigamma counter (Wallac, Turku).

Assay validation. Parallelism between standard and endogenous wallaby LH was tested by serial dilution of plasma from ovariectomized or castrate tammars and comparison with $\mathrm{NIH}$-oLH-S23. Pituitary homogenates prepared as described below were also compared with the NIH-oLH-S23 and ratLH-RP2 (data not shown). Sensitivity of the assay was $150 \mathrm{pg}$ $\mathrm{NIH}-\mathrm{oLH}-\mathrm{S} 23 \mathrm{ml}^{-1}$. Accuracy was determined by addition of $0,200,400,600$ and $800 \mathrm{pg}$ NIH-oLH-S23 to aliquots from a tammar plasma pool which were assayed as described above. The regression equation for NIH-oLH-S23 recovered from plasma against $\mathrm{LH}$ added to the plasma was $y=1.03 x$ +241.63 with $r=0.99$. Intra-assay $\mathrm{CV}$ for two different quality control pools containing 1.8 and $3.2 \mathrm{ng} \mathrm{ml}^{-1}$ were $13.8 \%$ and $20.8 \%$, respectively. Since all the samples were measured in a single assay, no interassay $\mathrm{CV}$ was calculated.

Pituitary homogenates. Pituitary extracts were prepared by homogenizing whole pituitaries from tammar wallaby, Eastern grey kangaroo, brushtail possum, Eastern quoll, kowari and Eastern pygmy possum in $0.1 \mathrm{ml}$ PBS on ice. The homogenates were made up to $3.0 \mathrm{ml}$ with distilled water and centrifuged at $1700 \mathrm{~g}$ for $10 \mathrm{~min}$. An aliquot $(0.5 \mathrm{ml})$ of each supernatant was made up to $5.0 \mathrm{ml}$ with PBS-BSA and this solution was diluted serially with PBS-BSA.

PGFM assay. PGFM was assayed by the method of Lewis et al. (1986). The assay sensitivity was $35 \mathrm{pg} \mathrm{ml}^{-1}$ plasma. The intra- and interassay $\mathrm{CV}_{\mathrm{s}}$ for a pool containing $1.16 \mathrm{ng} \mathrm{ml}^{-1}$ were $8.4 \%$ and $16.2 \%$, respectively.

\section{Statistical analyses}

Hormonal profiles were analysed by repeated measures analysis of variance. Time intervals between RPY and birth were compared by Student's $t$ test. Categoric data were analysed using the four-way table test for $2 \times 2$ tables.

\section{Results}

\section{Effects of treatment on the time of birth and fetal and neonatal} size

Five of six control animals in each trial were pregnant and delivered within the normal time (trial $\mathrm{I}: 27$ days $5.9 \mathrm{~h} \pm 12 \mathrm{~h}$ and trial 2: 26 days $21.9 \mathrm{~h} \pm 26.9 \mathrm{~h}$ ). The body mass of young from the control animals was $417.4 \pm 20.9 \mathrm{mg}$ (trial 1) or $397.4 \pm 26.6 \mathrm{mg}$ (trial 2). As these weights were not significantly different, they have been combined and so the mean mass for the ten controls is $407.4 \pm 24.9 \mathrm{mg}$. At autopsy on day 28, 6 of 6 (trial 1) and 6 of 6 (trial 2) animals treated with indomethacin had been pregnant, but none delivered live young. Two had aborted, as judged from the appearance of the endometrium (Ward and Renfree, 1984). Birth behaviour did not occur in these animals, and no trace of the aborted fetuses was found. Seven animals had dead fetuses and three had live fetuses. Nine of these ten fetuses were markedly post mature (Fig. 1). The remaining fetus was at the hind limb paddle stage normally reached at about day $24 \mathrm{RPY}$, and body mass was only $226 \mathrm{mg}$. It is presumed that reactivation was delayed and therefore the data for this animal are not included in the statistical analyses. The mean body mass of the treated fetuses recovered from the uterus was $470.6 \pm 70.7 \mathrm{mg}(n=5$, trial 1$)$ and $536.3 \pm 92.6 \mathrm{mg}(n=4$, trial 2). Again, these masses were not significantly different and so have been combined to give a mean fetal mass of $499.8 \pm 83.1 \mathrm{mg}(n=9)$. The fetuses of the treated females were significantly heavier than the neonatal controls $(P<0.005$, Student's $t$ test.)

All but one (in trial 2) of the control neonates gained weight within $12 \mathrm{~h}$ of their birth. In trial 1 , they gained a mean of $49.2 \pm 21.9 \mathrm{mg}$, and in trial $2,44.0 \pm 35.8 \mathrm{mg}$.

\section{Effects of treatment on oestrus and peripartum hormone concentrations}

Prolactin and prostaglandin. All control animals had a highly significant increase in concentration of PGFM at birth $(P<0.001$, samples prior to parturition versus samples taken $0-1 \mathrm{~h}$ after parturition), and in one animal in each control group PGFM concentrations had begun to rise $30 \mathrm{~min}$ before birth (Figs 2 and 3). The duration of the PGFM pulse was less than $1 \mathrm{~h}$, and the postpartum concentrations approximated prepartum values by $3 \mathrm{~h}$. The mean PGFM concentrations of the indomethacin treated animals were low at all time points. In individual animals, however, there was at least one sample with concentrations of PGFM significantly higher than the pre- and post-birth values.

All control animals had a marked rise in plasma prolactin within $30 \mathrm{~min}$ of birth (Figs 2 and 3). Prolactin concentrations were uniformly low in all samples taken earlier than $6 \mathrm{~h}$ before 

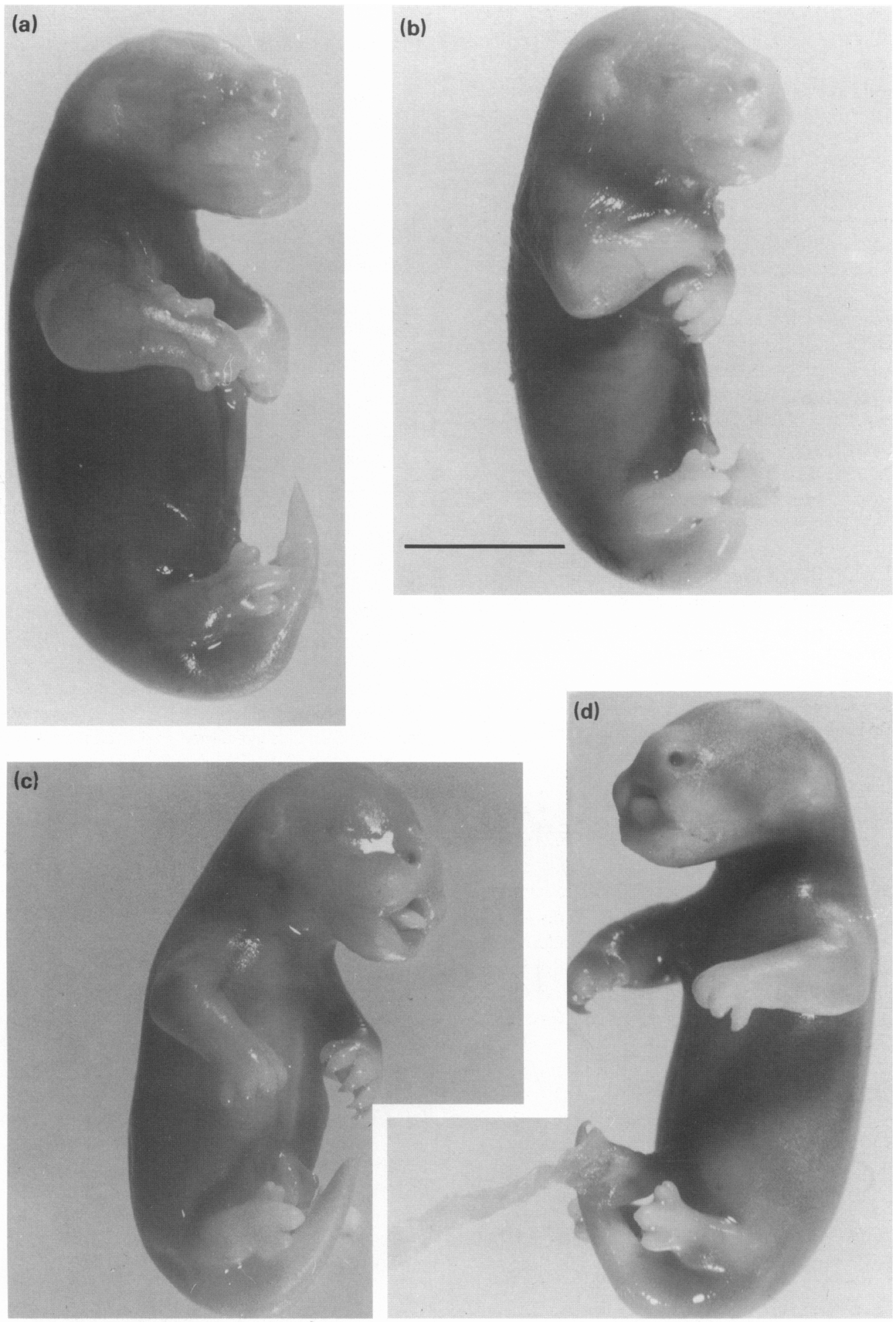

Fig. 1. Post mature fetuses recovered from the uteri of three female tammars treated with indomethacin $(a, c, d)$ and one fetus treated with indomethacin and bromocriptine (b). (a) crown-rump length, $21 \mathrm{~mm}, 653 \mathrm{mg}$ recovered dead; (b) crown-rump length, $18.1 \mathrm{~mm}, 559 \mathrm{mg}$ recovered dead; (c) crown-rump length, $17.6 \mathrm{~mm}$, $466 \mathrm{mg}$ recovered alive; (d) crown-rump length, $19.0 \mathrm{~mm}, 568 \mathrm{mg}$ recovered dead. For comparison, control neonates were $407 \mathrm{mg}$. Scale bar represents $5 \mathrm{~mm}$. 

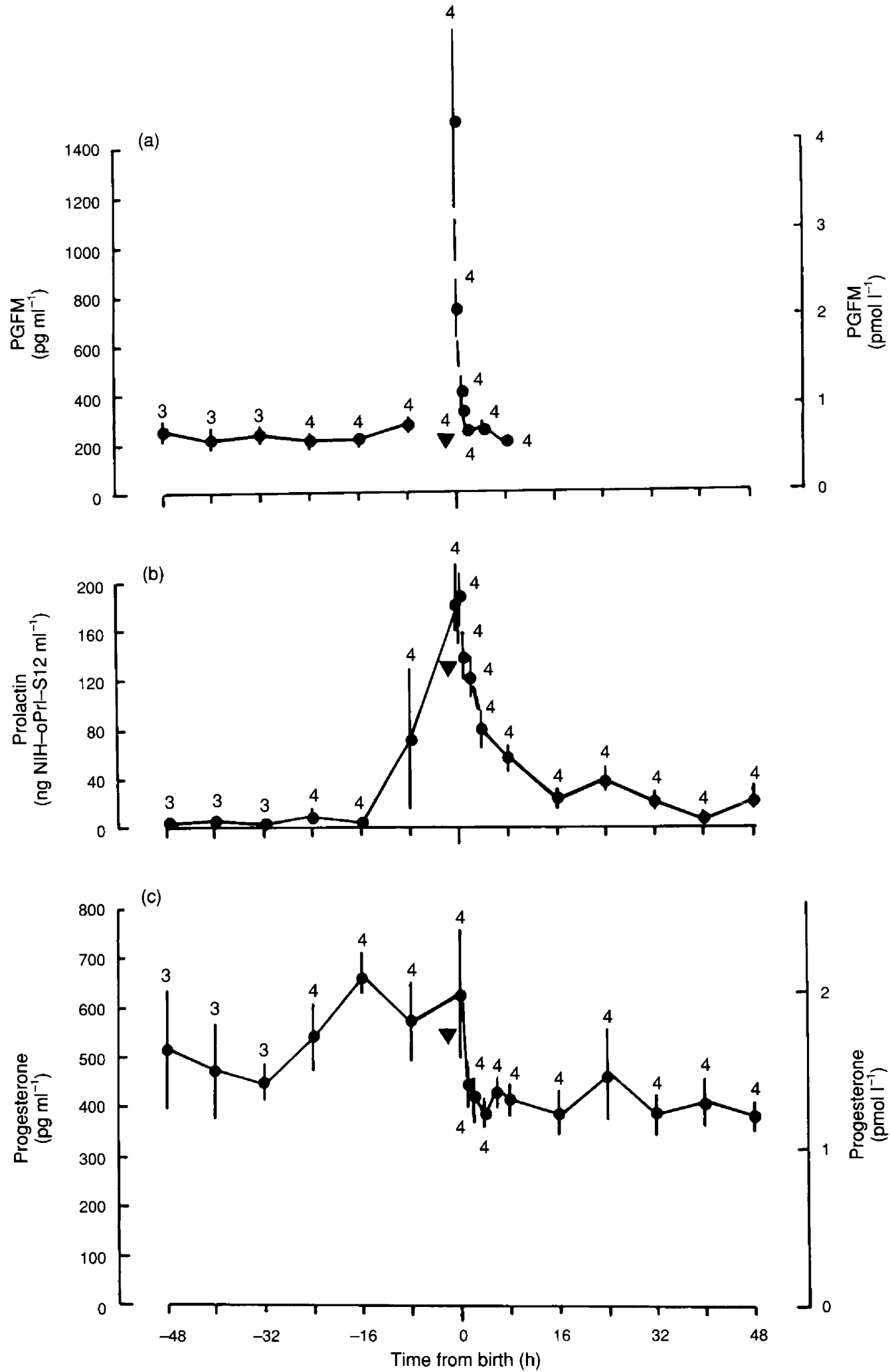

Fig. 2. Trial 1: plasma concentrations of (a) PGFM, (b) prolactin, and (c) progesterone in control animals synchronized around the time of parturition (time 0 ). Data are means \pm SEM; Number of samples at each time point is given above the point. Where $n=2$, no estimate of error is shown. The concentrations of PGFM and prolactin in samples taken soon after parturition were significantly greater than that in prepartum samples (repeated measures analysis of variance, $P<0.001$ ). Individual animals received saline injections $42-90 \mathrm{~h}$ before parturition; $(\boldsymbol{\nabla})$ shows values from a single animal sampled $30 \mathrm{~min}$ before birth. 

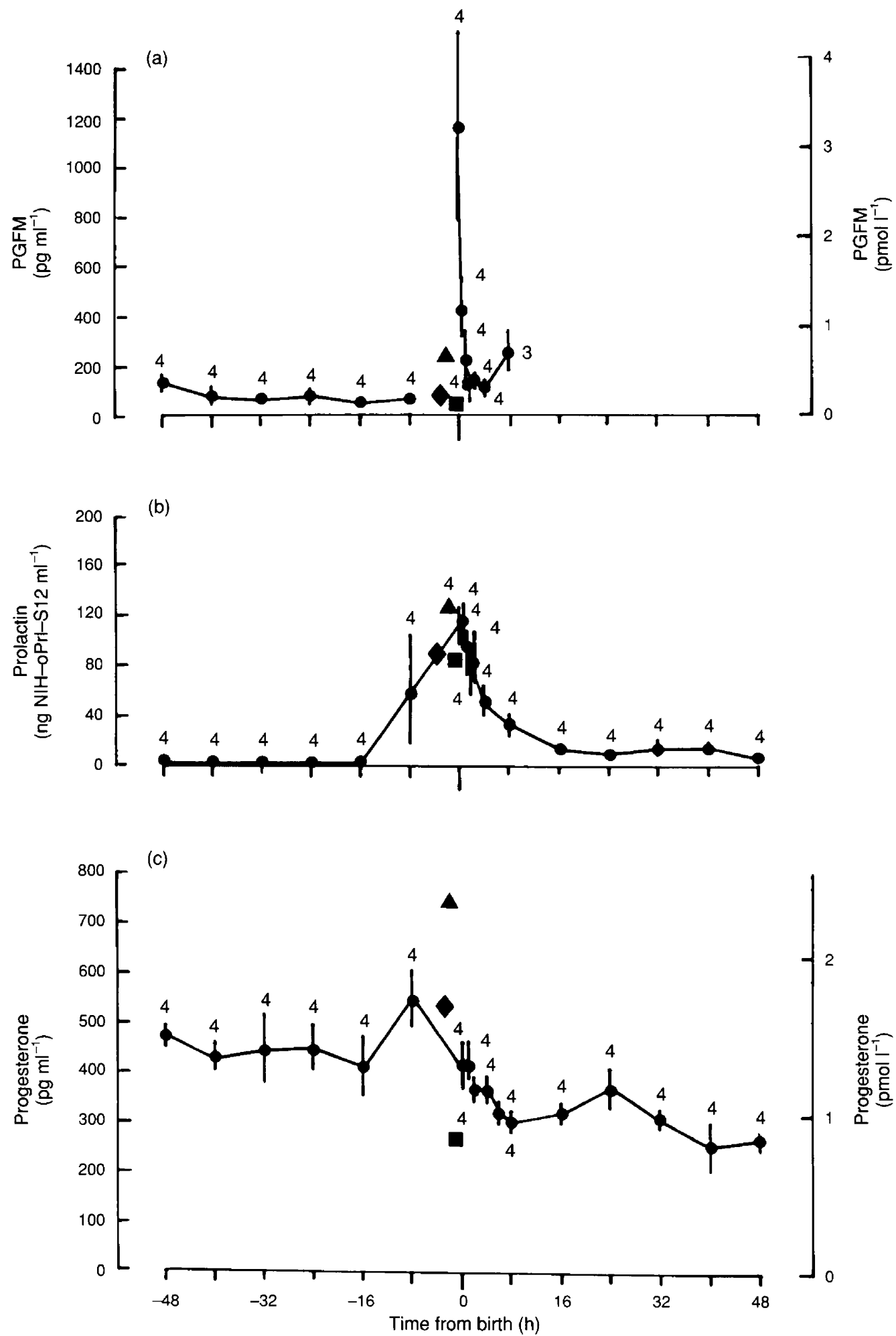

Fig. 3. Trial 2: plasma concentrations of (a) PGFM, (b) prolactin, and (c) progesterone in control animals synchronized around the time of parturition (time 0 ). Data are means \pm SEM; Number of samples at each time point is given above the point. Where $n=2$, no estimate of error is shown. The concentrations of PGFM and prolactin in samples taken soon after parturition were significantly greater than in prepartum samples (repeated measures anałysis of variance, $P<0.001$ ). Individual animals received saline injections $14-96 \mathrm{~h}$ before parturition; $(\boldsymbol{\Delta} \bullet$ ) show single values from three animals sampled 1-3 h before birth. 
(a)
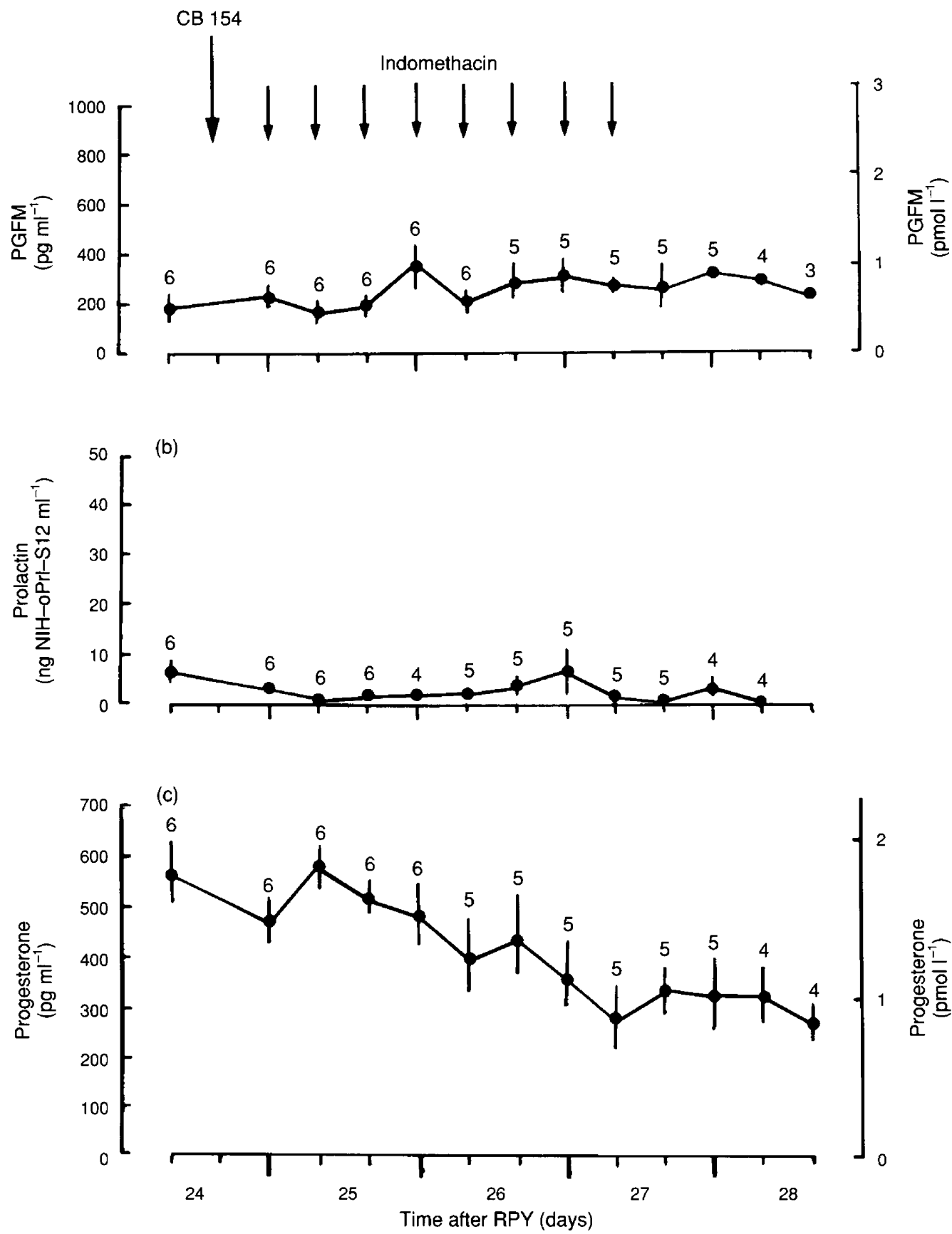

Fig. 4. Trial I: plasma profiles of (a) PGFM, (b) prolactin, and (c) progesterone concentrations in bromocriptine (CB154: heavy arrow) and indomethacin (lighter arrows) treated animals sampled from day 24 to day 28 after removal of pouch young (RPY). Data are means \pm sEM; Number of samples at each time point is given above the point. No significant changes were seen in PGFM or prolactin over the sampling period $(P>0.1$, repeated measures analysis of variance).

parturition. Prolactin was high at birth and for $4-6 \mathrm{~h}$ after birth. In two individual animals (one in each trial) prolactin was high before the peak prostaglandin concentrations were recorded. Concentrations had returned to prebirth values by about $32 \mathrm{~h}$ post partum.

Concentrations of prolactin in plasma of animals treated with indomethacin and bromocriptine were unchanged during the peripartum period $(P>0.1$, repeated measures analysis of variance), and no synchronization was evident between the sporadic plasma PGFM and prolactin rises that were seen in individual profiles.

Progesterone. Prebirth concentrations of progesterone ranged between 400 and $1000 \mathrm{ng} \mathrm{ml}^{-1}$. In both control 

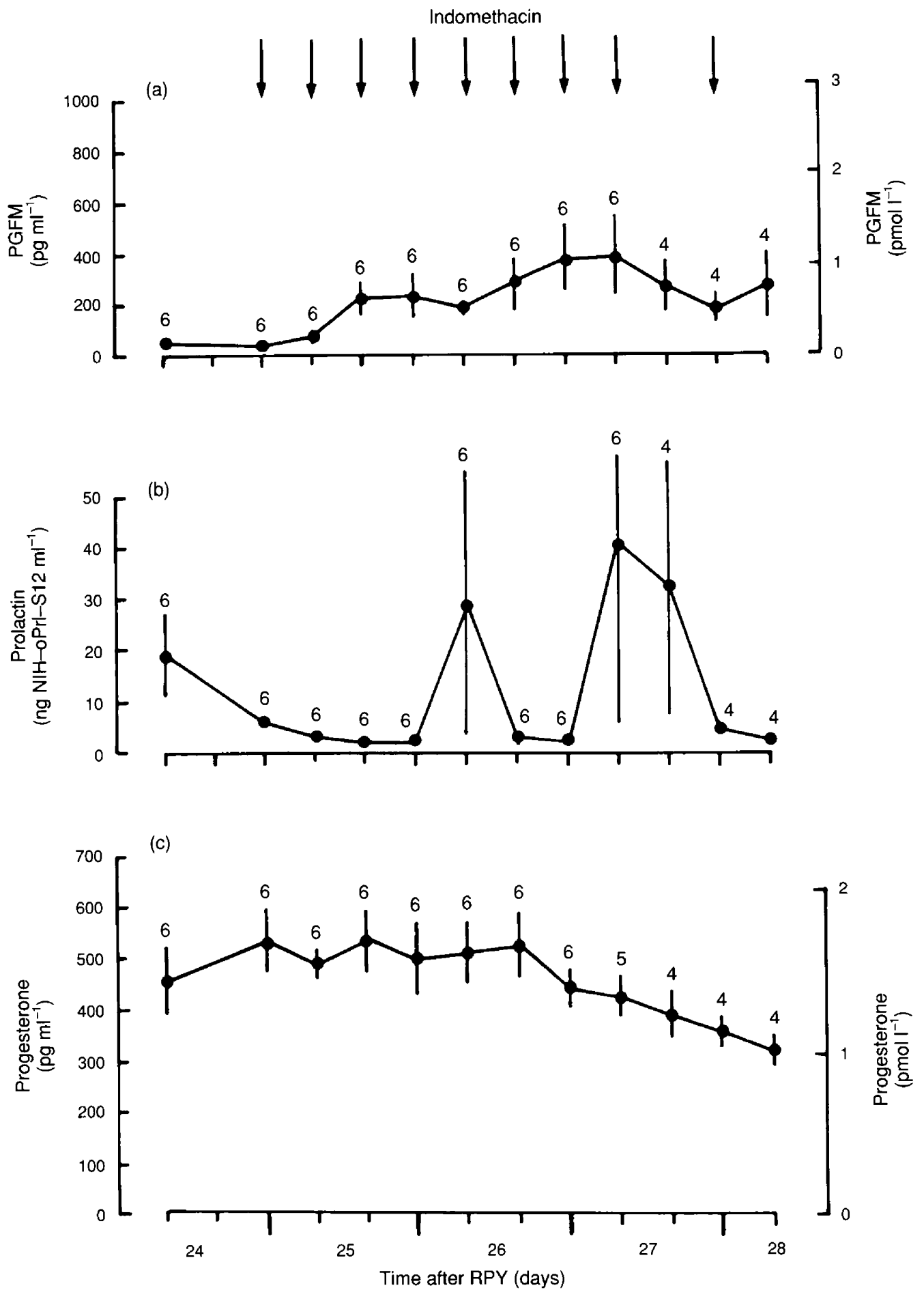

Fig. 5. Trial 2: plasma profiles of (a) PGFM, (b) prolactin, and (c) progesterone concentrations in indomethacin (arrows) treated animals sampled from day 24 to day 28 after removal of pouch young (RPY). Data are means \pm SEM; Number of samples at each time point is given above the point. No significant changes were seen in PGFM or prolactin over the sampling period ( $P>0.1$, repeated measures analysis of variance). However, individual females showed peaks of PGFM and prolactin that were not synchronized, leading to the large standard errors evident at some time points.

groups, a marked fall in progesterone to $300-350 \mathrm{pg} \mathrm{ml}^{-1}$ occurred within $1-2 \mathrm{~h}$ of birth (Figs 2 and 3). Progesterone values for each female from the last sample before birth and at $4 \mathrm{~h}$ and $24 \mathrm{~h}$ after birth were compared by repeated measures analysis of variance. There was a significant decrease in progesterone over the $24 \mathrm{~h}$ after 

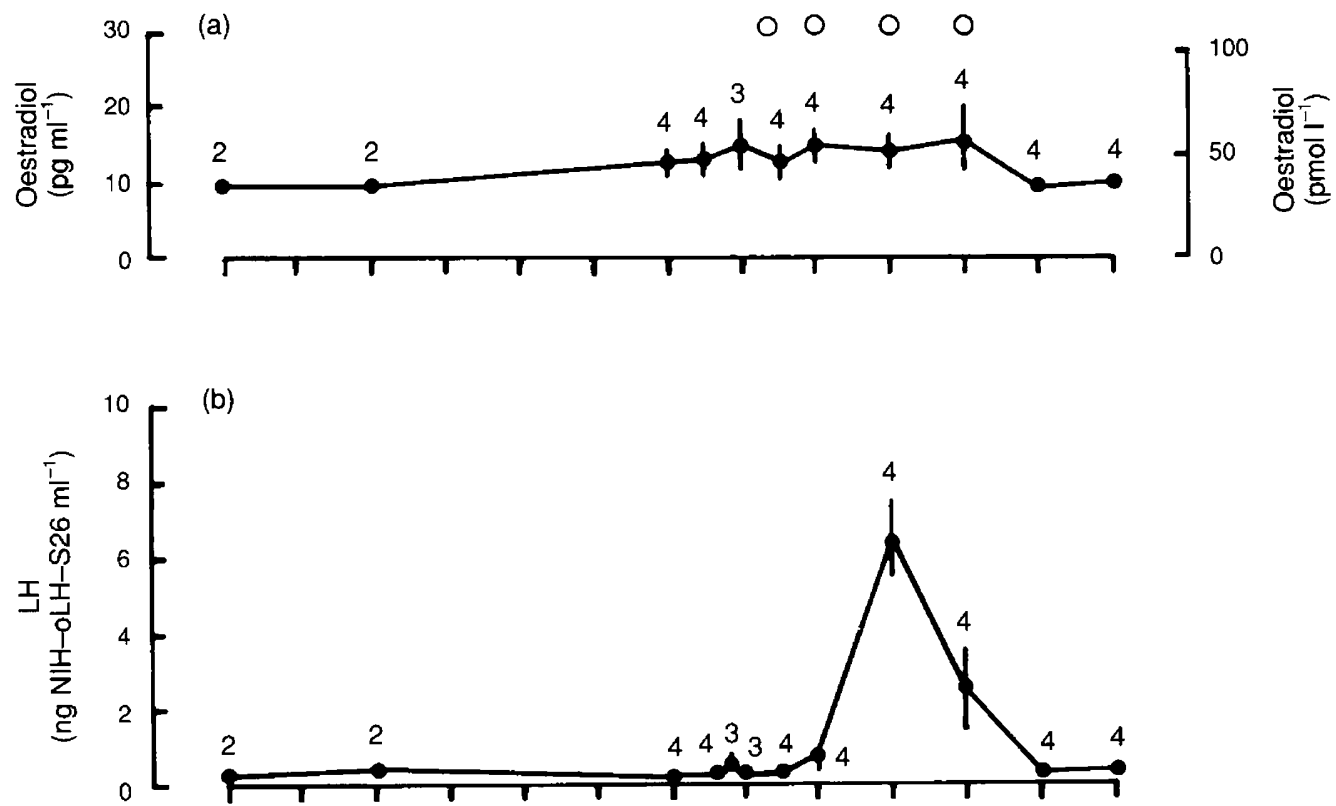

(b)
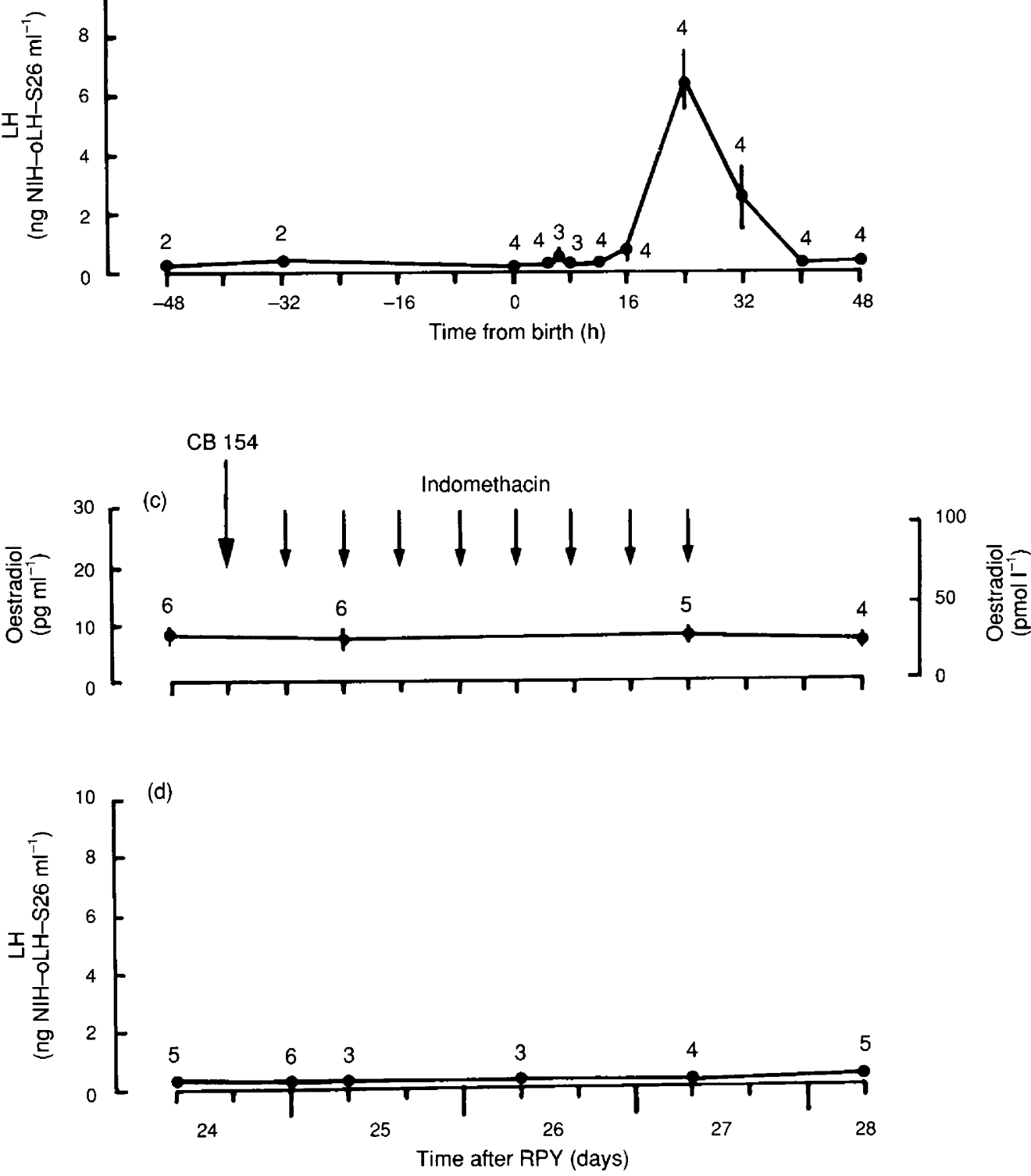

Fig. 6. Plasma oestradiol and LH concentrations around the time of parturition in control $(a, b)$ and bromocriptine and indomethacin treated $(c, d)$ wallabies. Data are means \pm SEM; Number of samples at each time point is given above the point. $O$ : the times that copulatory plugs were found in the four control animals that mated. In each case, the recorded mating was associated with a transiently increased oestradiol concentration and an LH pulse.

birth in both groups $(P<0.005)$, but no significant difference in the progesterone profile between the two groups $(P>0.1)$.
In the animals treated with indomethacin there were no precipitous falls in progesterone concentration in any individual treated animal, although there were definite irregular 

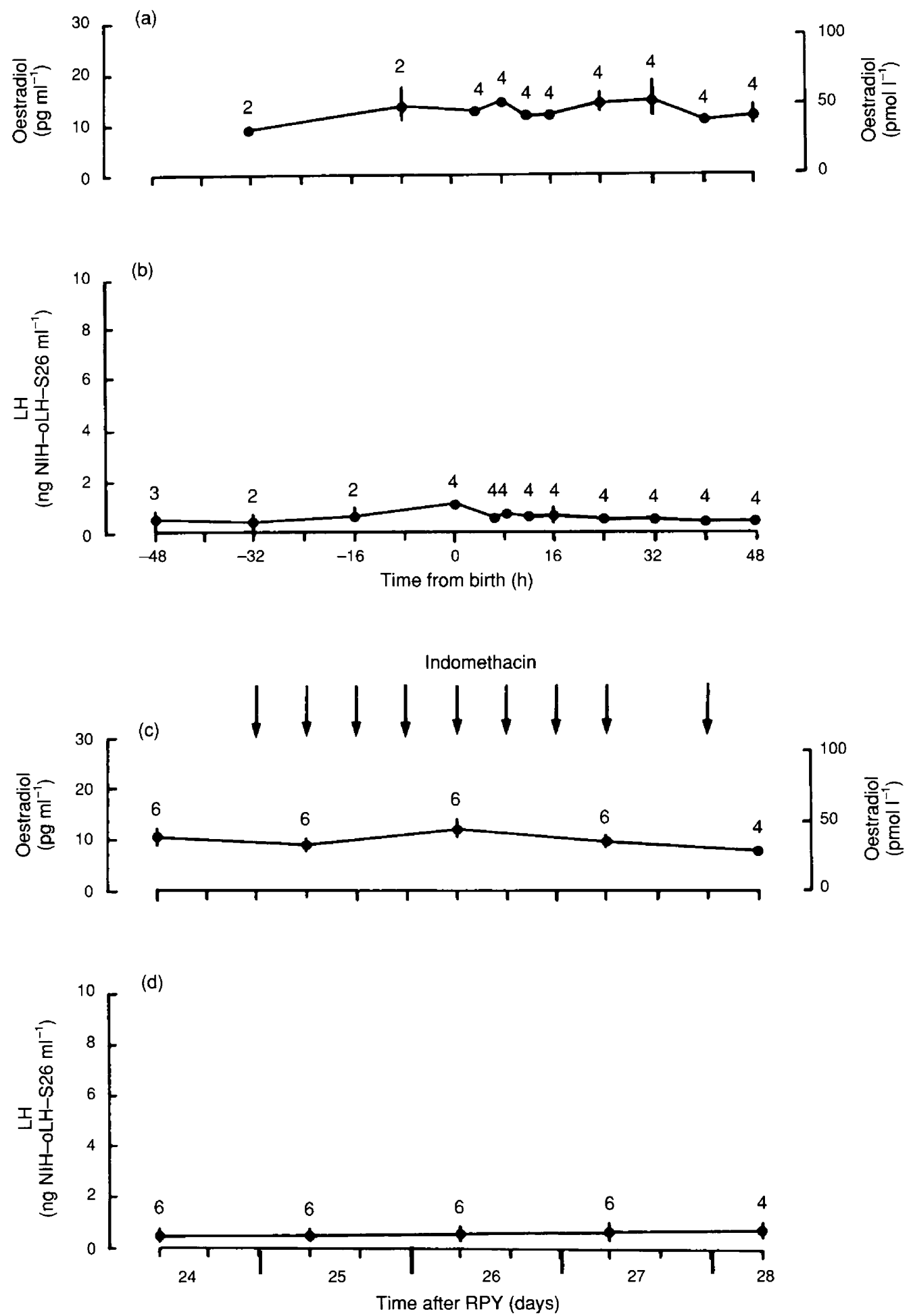

Fig. 7. Plasma oestradiol and LH concentrations around the time of parturition in control (a, b) and indomethacin treated ( $c, d)$ wallabies. Data are means \pm SEM; Number of samples at each time point is given above the point. Four of the five parturient controls had brief rises in oestradiol and $\mathrm{LH}$, but because the peaks occurred at different times, these are not seen in the mean values.

fluctuations in progesterone concentrations. Since there was no birth around which to synchronize the data, mean values for $8 \mathrm{~h}$ samples tend to flatten any peaks or troughs (Figs 4 and 5).
This pattern of luteolysis is like that seen in non-pregnant animals, despite the retained fetuses and absence of birth in these animals. 
Table 1. Occurrence of luteolysis during the oestrous cycle in response to administration of various combinations of exogenous prostaglandin and prolactin, and during pregnancy in response to inhibition of various combinations of endogenous prostaglandin and prolactin

\begin{tabular}{|c|c|c|c|}
\hline \multicolumn{4}{|c|}{ Nonpregnant cyclic animals } \\
\hline $\begin{array}{l}\text { Exogenous } \\
\text { prostaglandin }\end{array}$ & $\begin{array}{l}\text { Exogenous } \\
\text { prolactin }\end{array}$ & $\begin{array}{c}\text { Occurrence of } \\
\text { luteolysis }\end{array}$ & Source \\
\hline- & - & - & Assumed \\
\hline+ & $+*$ & + & Hinds et al., 1990 \\
\hline- & + & + & Tyndale-Biscoe et al., 1988 \\
\hline+ & - & - & Hinds, 1991 \\
\hline \multicolumn{4}{|c|}{ Pregnant animals } \\
\hline $\begin{array}{l}\text { Endogenous } \\
\text { prostaglandin }\end{array}$ & $\begin{array}{c}\text { Endogenous } \\
\text { prolactin }\end{array}$ & $\begin{array}{c}\text { Occurrence of } \\
\text { luteolysis }\end{array}$ & Source \\
\hline+ & - & + & Fletcher ef al, 1990 \\
\hline- & + & - & This study \\
\hline- & - & - & This study \\
\hline+ & + & + & $\begin{array}{l}\text { Tyndale-Biscoe et al., 1983; } \\
\text { Lewis et al., 1986; } \\
\text { Fletcher et al., } 1990\end{array}$ \\
\hline
\end{tabular}

*Endogenous prolactin pulse induced by prostaglandin injection.

Oestrus, oestradiol and LH. None of the five parturient controls mated immediately post partum in trial 1 , but four out of these five had copulatory plugs at $8,16,24$ and $32 \mathrm{~h}$ post partum (Fig. 6). None of the controls in trial 2 mated and none had plugs up to $48 \mathrm{~h}$ post partum. In each case the recorded mating was associated with high plasma oestradiol and an LH pulse. Four of the five parturient controls in trial 2 had high oestradiol and LH. This is not apparent from the mean values presented in Fig. I because the peaks occurred at different times post partum. None of the treated animals had an LH peak or a rise in oestradiol over the course of the experiment (Figs 6 and 7).

\section{Discussion}

Treatment with the prostaglandin synthase inhibitor indomethacin, with or without the prolactin inhibitor bromocriptine, disturbed the normal peripartum prostaglandin pulse, and prevented birth. In 10 of 12 control animals that gave birth, all had brief pulses of PGFM in the plasma at parturition similar to those previously reported (Lewis ef al., 1986; Fletcher et al., 1990). Rapid luteolysis occurred in all parturient animals, but was not induced by prolactin in the absence of prostaglandin or in the absence of both hormones. Subsequent oestrus occurred in only four animals, all of which were controls in trial 1, suggesting that mating behaviour is susceptible to disturbance. These results emphasize the importance of the rise in $\mathrm{PGF}_{2 \alpha}$ for successful parturition and luteolysis in tammars.
$\mathrm{PGF}_{2 \alpha}$ as well as large quantities of $\mathrm{PGE}_{2}$, are found in the endometrium and myometrium of late pregnant tammars (Shaw, 1983), so it has been assumed that the increase in plasma prostaglandin at parturition is of uterine origin (Lewis et al., 1986; Hinds et al., 1990). It is not yet established what initiates the parturient prostaglandin release, although the signal is apparently of fetal origin (Renfree et al., 1989; Hinds et al., 1990; Shaw et al., 1992; Renfree, 1993).

In normal pregnancy, progesterone concentrations of plasma fall rapidly about the time of parturition, coincident with the pulses of prolactin (Tyndale-Biscoe et al., 1988) and prostaglandin (Lewis et al., 1986) in the peripheral plasma. Exogenous prolactin on day 26 of the nonpregnant cycle causes immediate luteolysis (Tyndale-Biscoe et al., 1988; Hinds et al., 1990). However, in our experiment during pregnancy, rapid luteolysis was not seen in indomethacin-treated females, even though some had pulses of endogenous prolactin. Thus, in pregnant tammars prostaglandins appear to be luteolytic at birth. In nonpregnant females at the end of the cycle, progesterone concentrations still fall, but slowly over about 2 days (TyndaleBiscoe et al., 1983, 1988). Luteolysis has also been reported in the absence of the uterus in opossum (Hartman, 1925), brushtail possum (Clark and Sharman, 1965) and Bennett's wallaby (Loudon ef al., 1990). We postulate either that there is another luteolysin of extrauterine origin or, more simply, that the corpus luteum has a finite lifespan. The latter hypothesis is more consistent with the high degree of autonomy displayed by the corpora lutea of macropodid marsupials (Tyndale-Biscoe and Renfree, 1987) and is supported by the results of this study. In contrast, in nonpregnant tammars at the end of the 
oestrous cycle, exogenous prolactin, even in the absence of prostaglandin, is luteolytic (Tyndale-Biscoe et al., 1988; Hinds et al., 1990) and exogenous prostaglandin is not luteolytic in the absence of prolactin (Hinds, 1991). Thus prolactin, not prostaglandin, appears to be luteolytic in nonpregnant females.

Exogenous prostaglandin in nonpregnant females on day 26 of the cycle induces a surge of prolactin similar to the peripartum pulse (Hinds et al., 1990). A pulse of $\mathrm{PGF}_{2 \alpha}$ is not essential for a prolactin surge, since in two animals prolactin rose before the increase in prostaglandin concentrations at birth. However, slow luteolysis occurred in the present experiment in the absence of prolactin, as it does in nonpregnant animals (Tyndale-Biscoe et al., 1983) and in the absence of a synchronized prostaglandin pulse. The timing of luteolysis relative to days after RPY is different in nonpregnant animals when compared to pregnant animals. Loudon et al. (1990) also observed luteolysis in bromocriptine-treated Bennett's wallabies, but found a delay of 2 days in luteolysis compared with untreated controls. They did not measure PGFM but concluded that prostaglandins could have no role in luteolysis because hysterectomy did not prevent a progesterone decline.

Oestrus normally occurs within $1 \mathrm{~h}$ of parturition in tammars (Rudd, 1994), coincident with the increased oestradiol concentrations (Harder et al., 1984; Shaw and Renfree, 1984) that induce the $\mathrm{LH}$ surge and ovulation. These increases did not occur in any of the treated animals although, in four of five controls in trial 1 , oestradiol and LH concentrations rose and the animals mated, and in four of five in trial 2, oestradiol and LH concentrations rose but animals did not mate. We cannot explain this discrepancy except to suggest that April is closer to the end of the breeding season than March. Delay or inhibition of oestrus in animals disturbed by frequent sampling and handling have been noted before (Young and Renfree, 1979; Tyndale-Biscoe and Renfree, 1987; Fletcher et al., 1990) but are extremely difficult to avoid in an experiment of this design and it is possible that the level of stress was unexplainedly different in the two trials.

We conclude that the prostaglandin synthase inhibitor indomethacin interferes with the parturient release of prostaglandin, and delays parturition, regardless of the presence or absence of a prolactin pulse. The brief but high prostaglandin rise in pregnant females at term synchronizes a precipitate luteolysis, but in animals treated with indomethacin only a slow fall in progesterone was observed, regardless of the presence of a prolactin pulse. These results do not distinguish between the suggestions that the corpus luteum of the wallaby has an intrinsic control of its lifespan (Fletcher et al., 1990) via an intraluteal agent (Hinds, 1991), or that there is another luteolytic factor in macropodid marsupials (Loudon et al., 1990). Although the role of prostaglandin in Iuteolysis remains uncertain, our data demonstrate unequivocally that prostaglandin is essential for successful birth in the tammar.

The authors thank D. Taggart, A. Duns, O. Moran, B. Cannell and S. C. Williams for assistance with the collection of blood samples and the 'birth watch'. R. I. Cox (CSIRO Division of Animal Production, Blacktown, NSW) provided progesterone and oestradiol antisera. We are grateful to Sandoz Pharmaceuticals (Sydney, NSW) for the gift of bromocriptine pure substance. A. P. F. Flint (University of
Nottingham) kindly provided PGFM antiserum and A. S. McNeilly (MRC Reproductive Biology Unit, Edinburgh) the prolactin antiserum. Prolactin and LH standards and $\mathrm{LH}$ antiserum were obtained from the National Hormone and Pituitary Program (University of Maryland). Animals were held under permit number 88-53 from the Department of Conservation, Forests and Lands, Victoria, Australia.

\section{References}

Abraham GE (1969) Solid phase radioimmunoassay of estradiol-17 journal of Clinical Endocrinology and Metabolism $29866-870$

Burger HG, Lee VWK and Rennie GC (1972) A generalised computer program for the treatment of data from competitive protein-binding assays including radioimmunoassays Journal of Laboratory and Clinical Medicine 80 302-312

Clark MJ and Sharman GB (1965) Failure of hysterectomy to affect the ovarian cycle of the marsupial Trichosurus vulpecula Journal of Reproduction and Fertility $10459-461$

Fletcher TP and Renfree MB (1988) Effects of corpus luteum removal on progesterone, oestradiol-17 $\beta$ and LH in early pregnancy of the tammar wallaby, Macropus engenii Journal of Reproduction and Fertility 83 185-191

Fletcher TP, Shaw G and Renfree MB (1990) Effects of bromocriptine at parturition in the tammar wallaby, Macropus engenii Reproduction Fertility and Development 2 79-88

Gordon K, Fletcher TP and Renfree MB (1988) Reactivation of the quiescent corpus luteum and diapausing embryo after temporary removal of the sucking stimulus in the tammar wallaby (Macropus engenii) Journal of Reproduction and Fertility 83 401-406

Harder JD, Hinds LA, Horn CA and Tyndale-Biscoe CH (1984) Oestradiol in follicular fluid and in utero-ovarian venous and peripheral plasma during parturition and post partum oestrus in the tammar, Macropus engenii Journal of Reproduction and Fertility $\mathbf{7 2} 551-558$

Hartman CG (1925) Hysterectomy and the oestrous cycle in the opossum American Journal of Anatomy $3525-29$

Hinds LA (1991) Prostaglandin alone does not cause luteolysis in the nonpregnant tammar wallaby, Macropus eugenii Reproduction Fertility and Development 3 17-23

Hinds LA and Tyndale-Biscoe CH (1982) Plasma progesterone levels in the pregnant and non-pregnant tammar, Macropus eugenii Journal of Endocrinology 93 99-107

Hinds LA, Tyndale-Biscoe CH, Shaw G, Fletcher TP and Renfree MB (1990) Effects of prostaglandin and prolactin on luteolysis and parturient behaviour in the non-pregnant tammar, Macropus engenii Journal of Reproduction and Fertility $88 \quad 323-333$

Lewis PR, Fletcher TP and Renfree MB (1986) Prostaglandin in the peripheral plasma of tammar wallabies during parturition Journal of Endocrinology 111 103-109

Loudon A, Brinkelow BR, Gulland FD, Boyle J and Flint APF (1990) The roles of prolactin and the uterus in the control of luteal regression in the Bennett's wallaby (Macropus rufogriseus rufogriseus) Reproduction Fertility and Development 2 71-78

Renfree MB (1993) Endocrinology of pregnancy, parturition and lactation in marsupials. In Marshall's Physiology of Reproduction, 4th Edn Vol 3 Part 2 Chapter 7 pp 677-766 Ed. GE Lamming. Chapman and Hall, London

Renfree MB and Tyndale-Biscoe CH (1978) Manipulation of marsupial embryos and pouch young. In Methods in Mammalian Reproduction, pp 307-331 Ed. JC Daniel. Academic Press, New York

Renfree MB, Fletcher TP, Blanden DR, Lewis PR, Shaw G, Gordon K, Short RV, Parer-Cook E and Parer D (1989) Physiological and behavioural events around the time of birth in macropodid marsupials. In Kangaroos, Wallabies and Rat Kangaroos, pp 323-337 Eds P Jarman, ID Hume and G Grigg. Surrey Beatty and Sons Ltd, Sydney

Rudd CD (1994) Sexual behaviour of female and male tammar wallabies, Macropus engenii at postpartum oestrus Journal of Zoology 232 151-162

Shaw G (1983) Pregnancy After Diapause in the Tammar Wallaby, Macropus eugenii. PhD thesis, Murdoch University, Western Australia

Shaw G and Renfree MB (1984) Concentrations of oestradiol-17 $\beta$ in plasma and corpora lutea throughout pregnancy in the tammar, Macropus eugenii journal of Reproduction and Fertility 72 29-37

Shaw G, Fletcher TP and Renfree MB (1992) Corticosteroids induce early parturition in a marsupial Journal of Reproduction and Fertility Abstract Series 9 Abstract 135 
Thorell JI and Johannson BG (1971) Enzymatic iodination of polypeptides with ${ }^{125}$ I to high specific activity Biochimica et Biophysica Acta 251 363-369

Tyndale-Biscoe $\mathrm{CH}$ and Renfree MB (1987) Reproductive Physiology of Marsupials. Cambridge University Press.

Tyndale-Biscoe CH, Hinds LA, Horn CA and Jenkin G (1983) Hormonal changes at oestrus, parturition and post-partum oestrus in the tammar wallaby (Macropus eugenii) Journal of Endocrinology 96 155-161
Tyndale-Biscoe CH, Hinds LA and Horn CA (1988) Fetal role in the control of parturition in the tammar, Macropus eugenii Joumal of Reproduction and Fertility 82 419-428

Ward KL and Renfree MB (1984) Effects of progesterone on parturition in the tammar, Macropus eugenii Joumal of Reproduction and Fertility 72 21-28

Young IR and Renfree MB (1979) The effects of corpus luteum removal during gestation on parturition in the tammar wallaby (Macropus eugenii) Journal of Reproduction and Fertility 56 249-254 